\title{
Making Filipino Taekwondo Athletes Internationally Competitive: An International Comparison of Anthropometric and Physiologic Characteristics
}

\section{Janine Margarita R. Dizon ${ }^{1,2,3 *}$ and Karen Grimmer-Somers ${ }^{3}$}

${ }^{1}$ Philippine Centre for Sports Medicine, Philippine Sports Commission, Manila, Philippines

${ }^{2}$ University of Santo Tomas, Manila, Philippines

${ }^{3}$ International Centre for Allied Health Evidence, University of South Australia, Adelaide, Australia

\begin{abstract}
Recent focus has been on combat sports and one of which is taekwondo. Whilst the literature reports on several researches done among taekwondo athletes, nothing has been done to make practical comparisons of anthropometric and physiologic measures. This paper reports on research, which had the objectives of:

1. Establishing both an anthropometric and physiologic profile of elite Filipino taekwondo athletes and

2. Comparing the elite Filipino athletes' anthropometric and physiologic characteristics with published information on other elite athletes and provides useful information regarding components needed to be improved to enhance athletic performance.

Anthropometric and physiologic testing procedures were conducted to elite Filipino taekwondo athletes. A total of twenty Filipino athletes were assessed in this study. The results of these tests were compared with the data obtained from the identified international studies through a systematic search of the literature process. Outcomes available for comparison were extracted from each study. Five studies were obtained for comparison. The Filipino athletes were similar to other international elite athletes in most anthropometric measures. In the physiologic tests, it is worthy to note that the Filipino athletes, both male and female, had significantly better leg power test scores compared with their international counterparts; however, the female Filipino athletes scored less in flexibility and one minute sit up tests. The findings presented in this paper should be considered so that a greater scientific approach can be taken when designing athlete-specific, as well as team-specific training programs. Training programs that address the current physiological shortfalls should lead to improvements in national and international competition.
\end{abstract}

Keywords: Filipino; Anthropometric; Physiologic; Elite athletes; Taekwondo

\section{Introduction}

\section{Overview}

Elite athletes are generally characterized by a physique, optimal strength and endurance suited to the functional requirements of their sport $[1,2]$. These characteristics have been identified as anthropometric, physiologic and performance components and have been used to assess the fitness levels of athletes relevant to the requirements of their sport [3]. Evaluation of change in these components throughout a training program, and/or a season of competition are invaluable to athletes and coaches, as they provide information on the strengths and limitations of the athletes, and the influence of training programs [4]. This information facilitates development of individualized training programs to assist in optimal sports performance [5]. A number of sports profile studies have been published, mostly relating to endurance, racket and ball games sports [6-10]

\section{Combat sports}

A relatively recent focus has been on competitive combat sports because of their audience appeal, and the complex physical and mental challenges they offer to athletes. A search of the literature identified that competitive athlete anthropometric and physiologic profiles have been reported among athletes of pencak silat, judo and taekwondo [2,5,11-14]. These studies on combat sports either summarized findings on the assessment of traits and abilities and made some comparisons amongst different combat sports, correlated anthropometric profiles with physiologic profiles or correlated these profiles with sports performance. Competitive silat athletes were found to have lower aerobic fitness and grip strength, higher explosive leg power and comparable anaerobic capacity, compared with taekwondo and judo athletes [5]. Among male Brazilian judo athletes, those with bigger girth circumferences were stronger, those with higher percentage body fat performed poorer in the aerobic and special judo fitness tests and those with high aerobic power performed better in the high intensity intermittent exercises [11]. Amongst elite Czech taekwondo athletes, low levels of body fat, high anaerobic capacity, good aerobic capacity, strength and flexibility were relevant to good performance [12]. These studies had varying focus and none made direct comparisons among a similar group of combat sport.

\section{Taekwondo}

A prominent international combat sport is taekwondo. Taekwondo is characterized by fast and high kicks and traces its roots from a Korean martial art which was originally taught as self defense for warfare $[15,16]$. Today, it is an official international sport and there are

*Corresponding author: Janine Margarita R. Dizon, International Centre for Allied Health Evidence, University of South Australia, Adelaide, Australia, Tel: +63 9088687110; Fax: +632 7409713; E-mail: Janine.Dizon@unisa.edu.au

Received September 13, 2011; Accepted January 18, 2012; Published January 22, 2012

Citation: Dizon JMR, Grimmer-Somers K (2012) Making Filipino Taekwondo Athletes Internationally Competitive: An International Comparison of Anthropometric and Physiologic Characteristics. J Sport Medic Doping Studie 2:105. doi:10.4172/2161-0673.1000105

Copyright: (c) 2012 Dizon JMR, et al. This is an open-access article distributed under the terms of the Creative Commons Attribution License, which permits unrestricted use, distribution, and reproduction in any medium, provided the original author and source are credited. 
approximately 120 nations who are members of the World Taekwondo Federation (WTF) [15]. In the 1992 and 1998 Olympics, taekwondo was introduced as a demonstration sport; however since the 2000 Olympic Games in Sydney it has been included as part of the games competition [17].

\section{Taekwondo in the Philippines}

Taekwondo is a favorite recreational sport in the Philippines. The Philippine Taekwondo Association has been a member of the World Taekwondo Federation since 1973 [18]. Elite Filipino taekwondo athletes have been successfully competing in international competitions. During the 1992 Barcelona Olympic Games when taekwondo was a demonstration sport, two Filipino athletes won bronze medals [19]. More recently, there has been a growing interest amongst Filipinos to support, engage in, and succeed in taekwondo competitions.

Whilst the literature reports on several researches done among taekwondo athletes in terms of body fat and skinfold patterns [2], performance characteristics [20], injuries in competition [21], anthropometric and physiologic profile $[12,13,15]$ and responses during training [22], nothing has been done to make practical comparisons of anthropometric and physiologic measures. This is of particular importance to underpin the design of training programs in optimizing athletes' sports performance against their international counterparts. Therefore, this paper reports on research, which had the objectives of filling the identified gap in the body of literature by:

1. Establishing both an anthropometric and physiologic profile of elite Filipino taekwondo athletes and

2. Comparing the elite Filipino athletes' anthropometric and physiologic characteristics with published information on other elite athletes and provides useful information regarding components needed to be improved to enhance athletic performance.

\section{Methodology}

To fulfill the objectives of this study, this research has been divided into two parts:

1. Filipino athletes' anthropometric and physiologic testing and

2. Identification of international studies (which represent data of other elite international athletes) through a systematic review process to exhaust the literature, from which the Filipino data can be compared.

\section{Filipino athletes' data collection}

Ethical approval for this study was obtained from the College of Rehabilitation Sciences - Research Ethics Committee, University of Santo Tomas. All athletes who were eligible and agreed to participate in the study signed the written informed consent forms.

Participants: All elite taekwondo athletes from the Philippines national team were eligible to participate in the study. By definition, an elite athlete means that the athletes have the physique, optimal strength and endurance suited to the requirements of their sport [1,2] and were current members of the national team competing at an international level.

Methods: All consenting athletes were informed of the objectives and procedures of the study. They were instructed to comply with the preparations prior to testing, which includes ensuring eight hours of sleep, not engaging in a heavy training session and no caffeine or any form of energy enhancing substance on the day of the test [23].
As there are no gold standard tests used internationally, a battery of testing procedures were identified and used based on the validity and reliability of the tests (stated in each of the test measures below) as reported and recommended in the literature. The recommended order of administering the tests is - anthropometry, flexibility, agility, maximal strength and power, muscular endurance, sprint and aerobic power [24]. The athletes were given at least five minutes to recover after every test and allowed to rehydrate.

All testing equipment were tested and calibrated days before the scheduled testing to ensure that all are in good working condition. They were again calibrated on the day of the test to ensure accurate measurements are taken.

\section{Test battery:}

\section{Anthropometric Component:}

\section{Prior to stretching:}

1. Height was measured in centimeters using a stadiometer. The stretch stature method was utilized by having the athlete stand with their back and feet against the stadiometer. Height was measured as the maximum distance from the floor to the vertex of the head in the Frankfort plane [25]. This method of measuring height has been shown to have high ICC for test-retest reliability (0.99) and a small error of measurement $(0.2 \%)[26]$

2. Weight was measured in kilograms using a Detecto weighing scale. Athletes were asked to stand on the center of the weighing scale with minimal clothing. This method of measuring weight has been shown to have high ICC for test-retest reliability (0.99) and a small error of measurement (0.8\%) [26].

3. Skinfold measurement, with the use of a Lange fat caliper were taken in nine sites and were used to compute the percentage body fat. This method of assessing body fat has been shown to have high test-retest reliability ( $\mathrm{r}=0.98)$ [27]. The nine sites measured were triceps, biceps, subscapular, mid axilla, iliac, abdominal, suprailiac, mid thigh and calf. The average for each site was encoded, analyzed and finally reported as the percentage body fat using the Lifesize program software [28].

\section{Physiologic Component:}

\section{After stretching:}

1. Flexibility was measured in centimeters by the sit-and-reach test using the La Fayette sit and reach box (Model 01285A sit and reach flexibility test, LAFAYETTE, USA). The sit-andreach test gauges the flexibility of the hamstrings and lower back muscles, with a reliability measure of 0.92 [29]. Athletes were instructed to sit with their knees extended on the floor against the box. With hands on top of each other and palms facing down, the athletes pushed the ruler forward as far as possible without jerky movements.

2. Agility was assessed by the hexagon test (secs) using a stop watch. A hexagon measuring $60 \mathrm{~cm}$ on all sides at 120 degree angle was set up. At the start of the test, the athletes stood inside the hexagon and jumped out and in with both legs on all sides of the hexagon, completing three cycles. The test is finished after the third cycle and the athletes return to the starting position [30]. There was no published information found regarding the test-retest reliability of this test. 
Citation: Dizon JMR, Grimmer-Somers K (2012) Making Filipino Taekwondo Athletes Internationally Competitive: An International Comparison of Anthropometric and Physiologic Characteristics. J Sport Medic Doping Studie 2:105. doi:10.4172/2161-0673.1000105

Page 3 of 7

3. Local muscular strength was assessed by the one minute sit up test (repetitions). The one minute sit up test assesses the strength of the abdominal muscles and its ability to exert force to stabilize the trunk. The athletes lie supine with the hips and knees in 90 degree of flexion with arms crossed over the chest. Correct sit ups are ensured when the elbows touch the knees and the lower back touches the floor. The total number of sit ups completed over a period of one minutes was counted.

4. Leg power was measured by the vertical jump test $(\mathrm{cm})$ using the Swift yardstick device (Swift Yardstick, Swift Performance Equipment, Goonellabah, NSW, Australia). The vertical jump test is a good measure of lower leg explosive power. The athletes reached with their dominant arm as high as they could against the vane style apparatus to measure the initial reach height. Using a countermovement jump, the athletes jumped and reached as high as possible on the vane style apparatus. The ICC for test-retest reliability and TEM for the vertical jump is 0.96 and $3.3 \%$, respectively [26]

5. Speed test was measured by the use of the 10-meter sprint test (secs) using the Swift timing gate light. The 10-meter sprint is an excellent measure of anaerobic power (shorter time to finish, greater anaerobic power) and speed (rate of movement from one location to another). Athletes had to sprint a 10-meter distance in the shortest time possible without slowing down at the end. The ICC for test-retest reliability and TEM for the 10 -meter sprint is 0.97 and $1.3 \%$, respectively [26]

6. Aerobic power - Multi Stage Fitness Test (MSFT). This test involves continuous running between two lines 20-meters apart in time to recorded beeps. The test is made up of 23 levels where each level lasts approximately one minute. Each level comprises a series of 20-meter shuttles where the starting speed is $8.5 \mathrm{~km} / \mathrm{hr}$ and increases by $0.5 \mathrm{~km} / \mathrm{hr}$ at each level. On the tape a single beep indicates the end of a shuttle and 3 beeps indicates the start of the next level. The athletes' score is the level and number of shuttles reached before he/she is unable to keep up with the $\mathrm{CD}$ recording. This score can be converted to a predicted $\mathrm{VO}_{2} \max$ equivalent value [31]. The $\mathrm{VO}_{2} \max$ obtained in a MSFT is highly correlated $(\mathrm{r}=0.92)$ with $\mathrm{VO}_{2} \max$ levels obtained using the direct oxygen consumption test [32]. The ICC for test-retest reliability and TEM for the multi-stage fitness test are reported as 0.90 and $3.1 \%$, respectively [26].

Each of the tests (anthropometric and physiologic tests) was completed three times and conducted in the same order, except for the fatiguing tests (sit ups and MSFT). The average of the three trials was recorded and used for analysis.

\section{Identification of international studies for comparison}

This part of the methods section used a systematic review approach to search and exhaust the literature which reported on elite taekwondo athletes' anthropometric and physiologic performance profiles. Keywords were identified and used to search the following electronic databases: Ovid, Medline, SPORTDiscus, Google Scholar and Web of Knowledge. The search terms used are presented in Table 1.

To make the comparisons, means and standard deviations of the following were extracted using Microsoft excel sheets, from the identified studies:

- General information

gender and age
- Anthropometric test measures

- height, weight, percentage body fat

- Fitness measurements

- flexibility, agility, leg power, one minute sit up, sprint test, aerobic power test

\section{Statistical analysis}

Data collected from the Filipino athletes was analyzed using SAS Version 9.1. The data was described in terms of means and standard errors, or percentages. The Chi square test was used to analyze differences in gender.

Comparisons through statistical pooling were then made between the Filipino data and the data from other countries in terms of means, percentages and variability, as expressed in the overlap of $95 \%$ Confidence Intervals (CI). Data from the identified published studies on the physical and performance characteristics of international taekwondo elite athletes were summarized in terms of what information had been reported, how it was reported, and the relevant values to be used for comparison with the Filipino athletes. Where the international data reported only Standard Deviations, this was converted to standard errors and then to $95 \% \mathrm{CI}$, for comparison across the international taekwondo athlete samples.

It should be noted that comparisons were only possible for tests which were similar and valid measures of the anthropometric and physiologic components. Otherwise, no comparison was made. Comparisons per weight category were not considered in this study as most of the studies did not present findings using such categories.

\section{Results}

\section{Filipino elite athletes' sample}

All taekwondo athletes who are members of the national team met the inclusion criteria. A total of 20 athletes, who were (10 males and 10 females) were included in this study. The physical and physiologic characteristics are described in Table 2. There was no significant gender difference in all variables except for height $(\mathrm{p}<0.05)$, with males being taller than females.

\begin{tabular}{|l|l|l|l|}
\hline Keyword 1 AND & Keyword 2 AND & Keyword 3 AND & Keyword 4 \\
\hline Taekwondo OR & $\begin{array}{l}\text { Anthropometric } \\
\text { measurements OR }\end{array}$ & $\begin{array}{l}\text { Physiologic\$ } \\
\text { performance OR }\end{array}$ & Elite players OR \\
\hline Martial arts OR & Physique & Performance test\$ OR & Elite athletes OR \\
\hline Combat sports & & Fitness test\$ & National team \\
\hline
\end{tabular}

Table 1: Search terms used to identify studies from the literature.

\begin{tabular}{|l|c|c|}
\hline & Males $\mathbf{N = 1 0}$ & Females $\mathbf{N = 1 0}$ \\
\hline Age (years) & $23.8 \pm 2.3$ & $21.4 \pm 3.3$ \\
\hline Height (cm)* & $173.4 \pm 5.7$ & $165.0 \pm 6.6$ \\
\hline Weight (kg) & $70.7 \pm 14.0$ & $62.0 \pm 6.9$ \\
\hline Percentage body fat (\%) & $11.4 \pm 5.2$ & $23.5 \pm 4.0$ \\
\hline Sit and reach test for flexibility (cm) & $38.6 \pm 6.6$ & $36.6 \pm 8.4$ \\
\hline Hexagon test for agility (secs) & $11.4 \pm 1.2$ & $12.8 \pm 1.8$ \\
\hline Leg power test (cm) & $25.0 \pm 3.7$ & $17.9 \pm 1.7$ \\
\hline $\begin{array}{l}\text { One minute sit up test for local muscle } \\
\text { strength (reps) }\end{array}$ & $42.0 \pm 7.6$ & $39.3 \pm 5.6$ \\
\hline 10 meter Sprint test (secs) & $2.3 \pm 0.1$ & $2.6 \pm 0.1$ \\
\hline MSFT for aerobic power (ml/O2/kg/min) & $50.5 \pm 5.0$ & $38.1 \pm 6.1$ \\
\hline
\end{tabular}

*significant difference $(p<0.05)$

Table 2: Age, Anthropometric and Physiologic characteristics of 2008 elite Filipino athletes described in means and SD. 
Citation: Dizon JMR, Grimmer-Somers K (2012) Making Filipino Taekwondo Athletes Internationally Competitive: An International Comparison of Anthropometric and Physiologic Characteristics. J Sport Medic Doping Studie 2:105. doi:10.4172/2161-0673.1000105

Page 4 of 7

\section{Search for studies for international comparison}

The literature search for international studies identified 32 articles on combat sports which were narrowed down to five (5) studies on taekwondo for comparison. Characteristics of the five individual studies and available data for extraction are presented in Table 3.

\section{Anthropometric comparisons}

The anthropometric characteristics of Filipino taekwondo athletes and the elite athletes from other countries are presented in Tables 4 (males) and 5 (females). Table 4 highlights that the Filipino male athletes were not different from the other international athletes in age and weight. Body fat levels were not compared as completely different tests were used as measures for this outcome. However, there is a trend towards significance in terms of height comparison with the Filipino male athletes measuring shorter than their counterparts (Figure 1). This trend towards significance is indicated by largely different confidence intervals.

The elite Filipino female athletes were not different from the other elite female samples reported in the literature in terms of age, height and weight. Varying body fat levels were noted among the groups. However, direct comparisons cannot be made due to the difference in the number of skinfold measures taken to obtained the percentage body fat levels (Table 5).

Table 6 describes the different studies from the literature which reported on physiologic tests conducted and the scores of the taekwondo athletes. There was variability in the components of fitness assessed and the tests used to measure the components which made direct comparisons difficult. For male athletes, comparisons were only possible for flexibility and leg power. For the female athletes, comparisons were possible for flexibility, leg power, and the one minute sit up test. Confidence intervals were computed for tests in which it was possible to compare both male and female athletes.

Among the male athletes, there was no difference for flexibility. However, for leg power, there was a significant difference as there was no overlap of CI between the two groups of male athletes. Male Filipino

\begin{tabular}{|c|c|c|c|c|c|}
\hline & Heller et al 1998 & Rivera et al 1998 & Markovic et al 2005 & Kazemi et al 2006 & Kazemi et al 2009 \\
\hline Country & Czech Republic & Puerto Rico & Croatia & 2000 (Sydney) Olympic Games Participants & $\begin{array}{l}2004 \text { (Athens) } \\
\text { Olympic Games Participants }\end{array}$ \\
\hline Gender & Males and females & Females only & Females only & Males and females & Males and females \\
\hline Age & $\sqrt{ }$ & $\sqrt{ }$ & $\sqrt{ }$ & $\sqrt{ }$ & $\sqrt{ }$ \\
\hline Height & $\sqrt{ }$ & $\sqrt{ }$ & $\sqrt{ }$ & $\sqrt{ }$ & $\sqrt{ }$ \\
\hline Weight & $\sqrt{ }$ & $\sqrt{ }$ & $\sqrt{ }$ & $\sqrt{ }$ & $\sqrt{ }$ \\
\hline Body fat $\%$ & $\sqrt{ }$ & $\sqrt{ }$ & $\sqrt{ }$ & $x$ & $\mathrm{X}$ \\
\hline Flexibility test & $\sqrt{ }$ & $\mathrm{x}$ & $\sqrt{ }$ & $x$ & $x$ \\
\hline Agility test & $x$ & $\mathrm{x}$ & $\sqrt{ }$ & $x$ & $x$ \\
\hline Leg power test & $\sqrt{ }$ & $x$ & $\sqrt{ }$ & $x$ & $x$ \\
\hline 1 min sit up test & $x$ & $x$ & $\sqrt{ }$ & $x$ & $x$ \\
\hline Sprint test & $X$ & $\mathrm{X}$ & $\sqrt{ }$ & $x$ & $x$ \\
\hline Aerobic test & $\sqrt{ }$ & $\mathrm{X}$ & $\sqrt{ }$ & $x$ & $x$ \\
\hline
\end{tabular}

Table 3: Characteristics of studies and data available for extraction and comparison.

\begin{tabular}{|c|c|c|c|c|c|c|}
\hline & $\begin{array}{l}\text { Heller et al } 1998 \\
\text { (Czech athletes) } \\
\mathrm{N}=11\end{array}$ & $\begin{array}{l}\text { Kazemi et al } 2006 \\
\text { (2000 Olympic } \\
\text { winners) } \\
\mathrm{N}=16\end{array}$ & $\begin{array}{l}\text { Kazemi et al } 2006 \\
\text { (2000 Olympic non } \\
\text {-winners) } \\
\mathrm{N}=38\end{array}$ & $\begin{array}{l}\text { Kazemi et al } 2009 \\
\text { (2004 Olympic } \\
\text { winners) } \\
\mathrm{N}=12\end{array}$ & $\begin{array}{l}\text { Kazemi et al } 2009 \\
\text { (2004 Olympic non } \\
\text {-winners) } \\
\mathrm{N}=52\end{array}$ & $\begin{array}{l}2008 \text { Filipino athletes } \\
\mathrm{N}=10\end{array}$ \\
\hline Age (years) & $\begin{array}{c}20.9 \pm 2.2 \\
{[19.6-22.2]}\end{array}$ & $\begin{array}{c}24.4 \pm 3.3 \\
{[22.8-26.0]}\end{array}$ & $\begin{array}{c}25.2 \pm 4.3 \\
{[23.8-26.6]}\end{array}$ & $\begin{array}{c}26.1 \pm 4.6 \\
{[23.5-28.7]}\end{array}$ & $\begin{array}{c}26.0 \pm 4.3 \\
{[24.8-27.2]}\end{array}$ & $\begin{array}{r}23.8 \pm 2.3 \\
{[22.4-25.2]}\end{array}$ \\
\hline Height (cm) & $\begin{array}{l}179.0 \pm 6.0 \\
{[175.5-182.5]}\end{array}$ & $\begin{array}{l}183.0 \pm 8.0 \\
{[179.1-186.9]}\end{array}$ & $\begin{array}{l}179.0 \pm 8.0 \\
{[176.5-181.5]}\end{array}$ & $\begin{array}{l}183.0 \pm 1.1 \\
{[182.4-183.6]}\end{array}$ & $\begin{array}{l}181.0 \pm 0.8 \\
{[180.8-181.2]}\end{array}$ & $\begin{array}{l}173.4 \pm 5.7 \\
{[169.9-176.9]}\end{array}$ \\
\hline Weight (kg) & $\begin{array}{c}69.9 \pm 8.7 \\
{[64.8-75.0]}\end{array}$ & $\begin{array}{r}73.4 \pm 12.1 \\
{[67.5-79.3]}\end{array}$ & $\begin{array}{r}73.7 \pm 14.3 \\
{[69.2-78.2]}\end{array}$ & $\begin{array}{r}75.8 \pm 16.1 \\
{[66.7-84.9]}\end{array}$ & $\begin{array}{r}74.1 \pm 13.0 \\
{[70.6-77.6]}\end{array}$ & $\begin{array}{r}70.7 \pm 14.0 \\
{[62.0-79.4]}\end{array}$ \\
\hline Body fat (\%) & $\begin{array}{c}8.2 \pm 3.1 \\
(10 \text { skinfold measures })\end{array}$ & Not assessed & Not assessed & Not assessed & Not assessed & $\begin{array}{l}11.4 \pm 5.2 \\
\text { (9 skinfold measures) }\end{array}$ \\
\hline
\end{tabular}

Table 4: Elite Filipino male athletes anthropometric comparisons to other athletes reported in the literature expressed in means, SD and 95\% Cl.

\begin{tabular}{|c|c|c|c|c|c|c|c|c|}
\hline & $\begin{array}{l}\text { Heller et al } 1998 \\
\text { (Czech athletes) } \\
\mathrm{N}=12\end{array}$ & $\begin{array}{l}\text { Rivera et al } 1998 \\
\text { (Puerto Rican } \\
\text { athletes) } \\
\mathrm{N}=9\end{array}$ & $\begin{array}{l}\text { Markovic et al } \\
2005 \\
\text { (Croatian } \\
\text { athletes) } \\
\mathrm{N}=13\end{array}$ & $\begin{array}{l}\text { Kazemi et al } \\
2006 \\
(2000 \text { Olympic } \\
\text { winners) } \\
N=16\end{array}$ & $\begin{array}{l}\text { Kazemi et al } \\
2006 \\
(2000 \text { Olympic } \\
\text { non -winners) } \\
\mathrm{N}=32\end{array}$ & $\begin{array}{l}\text { Kazemi et al } \\
2009 \\
\text { (2004 Olympic } \\
\text { winners) } \\
\mathrm{N}=12\end{array}$ & $\begin{array}{l}\text { Kazemi et al } \\
2009 \\
\text { (2004 Olympic } \\
\text { non -winners) } \\
N=48\end{array}$ & $\begin{array}{l}2008 \text { Filipino } \\
\text { athletes } \\
\mathrm{N}=10\end{array}$ \\
\hline Age (years) & $\begin{array}{l}18.5 \pm 2.6 \\
{[17.0-20.0]}\end{array}$ & $\begin{array}{l}18.1 \pm 3.4 \\
{[15.9-20.3]}\end{array}$ & $\begin{array}{l}21.5 \pm 4.1 \\
{[19.3-23.7]}\end{array}$ & $\begin{array}{l}23.1 \pm 3.9 \\
{[21.2-25.0]}\end{array}$ & $\begin{array}{l}24.9 \pm 4.7 \\
{[23.3-26.5]}\end{array}$ & $\begin{array}{c}24.3 \pm 4.9 \\
{[21.5-27.1]}\end{array}$ & $\begin{array}{c}24.5 \pm 4.7 \\
{[23.2-25.8]}\end{array}$ & $\begin{array}{l}21.4 \pm 3.3 \\
{[19.3-23.4]}\end{array}$ \\
\hline Height (cm) & $\begin{array}{l}168.0 \pm 5.0 \\
{[165.2-170.8]}\end{array}$ & $\begin{array}{l}163.7 \pm 6.9 \\
{[159.2-168.2]}\end{array}$ & $\begin{array}{l}168.0 \pm 6.6 \\
{[164.4-171.6]}\end{array}$ & $\begin{array}{l}170.0 \pm 7.0 \\
{[166.6-173.4]}\end{array}$ & $\begin{array}{l}169.0 \pm 8.0 \\
{[166.2-171.8]}\end{array}$ & $\begin{array}{l}173.0 \pm 0.6 \\
{[172.7-173.3]}\end{array}$ & $\begin{array}{l}169.0 \pm 0.7 \\
168.8-169.2]\end{array}$ & $\begin{array}{l}165.0 \pm 6.6 \\
{[160.9-169.1]}\end{array}$ \\
\hline Weight (kg) & $\begin{array}{l}62.3 \pm 7.4 \\
{[58.1-66.5]}\end{array}$ & $\begin{array}{l}58.6 \pm 11.2 \\
{[51.3-65.9]}\end{array}$ & $\begin{array}{l}60.1 \pm 9.0 \\
{[55.2-65.0]}\end{array}$ & $\begin{array}{l}60.3 \pm 9.1 \\
{[55.8-64.8]}\end{array}$ & $\begin{array}{l}61.3 \pm 10.9 \\
{[57.5-65.1]}\end{array}$ & $\begin{array}{l}61.3 \pm 10.5 \\
{[55.4-67.2]}\end{array}$ & $\begin{array}{c}60.9 \pm 9.4 \\
{[58.2-63.6]}\end{array}$ & $\begin{array}{l}62.0 \pm 6.9 \\
{[57.7-66.3]}\end{array}$ \\
\hline Body fat (\%) & $\begin{array}{l}15.4 \pm 5.1 \\
(10 \text { skinfold } \\
\text { measures) }\end{array}$ & $18.3 \pm 5.6$ & $\begin{array}{l}16.5 \pm 2.7 \\
\text { (4 skinfold } \\
\text { measures) }\end{array}$ & Not assessed & Not assessed & Not assessed & Not assessed & $\begin{array}{l}23.5 \pm 4 \\
(9 \text { skinfold } \\
\text { measures })\end{array}$ \\
\hline
\end{tabular}

Table 5: Elite Filipino female athletes anthropometric comparisons to other athletes reported in the literature expressed in means, SD and $95 \% \mathrm{Cl}$. 
Citation: Dizon JMR, Grimmer-Somers K (2012) Making Filipino Taekwondo Athletes Internationally Competitive: An International Comparison of Anthropometric and Physiologic Characteristics. J Sport Medic Doping Studie 2:105. doi:10.4172/2161-0673.1000105

Page 5 of 7

\begin{tabular}{|c|c|c|c|c|c|}
\hline \multirow[t]{2}{*}{ Fitness Component Assessed } & \multicolumn{2}{|l|}{$\begin{array}{l}\text { Heller et al } 1998 \\
\text { (Czech athletes) }\end{array}$} & \multirow{2}{*}{\begin{tabular}{|l} 
Markovic et al 2005 \\
(Croatian athletes)
\end{tabular}} & \multicolumn{2}{|c|}{2008 Filipino athletes } \\
\hline & Males & Females & & Males & Females \\
\hline Flexibility $(\mathrm{cm})$ & $\begin{array}{l}36.9 \pm 4.5 \\
{[34.2-40.0]}\end{array}$ & $\begin{array}{l}37.9+3.4 \\
{[36.0-40.0]}\end{array}$ & $\begin{array}{l}55.8+4.8 \\
{[53.2-58.4]}\end{array}$ & $\begin{array}{l}38.6+6.6 \\
{[34.5-42.7]}\end{array}$ & $\begin{array}{l}36.6+8.4 \\
{[31.4-41.8]}\end{array}$ \\
\hline Agility (secs) & Not conducted & Not conducted & $\begin{array}{l}8.0 \pm 0.3 \\
\text { *Side step test }\end{array}$ & $\begin{array}{l}11.4 \pm 1.2 \\
\text { *Hexagon test }\end{array}$ & $\begin{array}{l}12.8 \pm 1.8 \\
\text { *Hexagon test }\end{array}$ \\
\hline Leg power using countermovement jump test $(\mathrm{cm})$ & $\begin{array}{l}45.4 \pm 4.5 \\
{[42.7-48.1]}\end{array}$ & $\begin{array}{l}29.8 \pm 4.0 \\
{[27.5-32.1]}\end{array}$ & $\begin{array}{l}30.6 \pm 3.4 \\
{[28.8-32.4]}\end{array}$ & $\begin{array}{l}63.5 \pm 9.4 \\
{[57.7-69.3]}\end{array}$ & $\begin{array}{l}48.1 \pm 4.3 \\
{[42.8-48.1]}\end{array}$ \\
\hline One minute sit up test (reps) & Not conducted & Not conducted & $\begin{array}{l}55.2 \pm 6.1 \\
{[51.9-58.5]}\end{array}$ & $42.0 \pm 7.6$ & $\begin{array}{l}39.3 \pm 5.6 \\
{[35.8-42.8]}\end{array}$ \\
\hline $\begin{array}{l}\text { Local Muscular Endurance using the } 2 \text { minute sit up test } \\
\text { (reps) }\end{array}$ & Not conducted & Not conducted & Not conducted & $70.9 \pm 21.6$ & $71.6 \pm 10.4$ \\
\hline Sprint test (secs) & Not conducted & Not conducted & $\begin{array}{l}3.7 \pm 0.2 \\
* 20 m \text { sprint }\end{array}$ & $\begin{array}{l}2.3 \pm 0.1 \\
* 10 m \text { sprint }\end{array}$ & $\begin{array}{l}2.6 \pm 0.1 \\
* 10 m \text { sprint }\end{array}$ \\
\hline Aerobic power (ml/O2/kg/min) & $\begin{array}{l}53.9 \pm 4.4 \\
\text { *direct } \mathrm{O} 2 \text { consumption }\end{array}$ & $\begin{array}{l}41.6 \pm 4.2 \\
{ }^{*} \text { direct } \mathrm{O} 2 \text { consumption }\end{array}$ & $\begin{array}{l}48.3 \pm 2.8 \\
* \text { direct } \mathrm{O} 2 \text { consumption }\end{array}$ & $\begin{array}{l}50.5 \pm 5 \\
{ }^{*} M S F T\end{array}$ & $\begin{array}{l}38.1 \pm 6.1 \\
{ }^{*} M S F T\end{array}$ \\
\hline
\end{tabular}

*specific tests administered; shaded columns represent male data

Table 6: Comparison of physiologic tests of elite Filipino athletes from those reported in the literature expressed in means, SD and $95 \% \mathrm{Cl}$.

athletes had higher scores in leg power test than the male Czech athletes (Figure 2).

Among female athletes, a variety of findings were found in the comparisons made. In the flexibility test, female Filipino athletes performed as well as the Czech athletes but poorer than the Croatian athletes (Figure 3). In the leg power tests, the female Filipino athletes performed significantly better than their international counterparts (Figure 4). In the one minute sit up test, there was a significant difference with the Filipino athletes scoring less than the female Croatian athletes (Figure 5).

\section{Discussion}

This study aimed to present an anthropometric and physiologic profile of elite Filipino taekwondo athletes which was used to compare the Filipino's test results with that of their international counterparts. The data on international athletes reflected the winners and the non winners of the 2000 and 2004 Olympic Games and other athletes from different countries. This study highlights the importance of making comparisons in the way presented in this study. Athletes are trained to reach optimum sports performance, of which the ultimate goal is to excel among their international counterparts. Thus the comparison reported in this paper should assist the Philippines in particular, to establish a training program which improves on the physiologic characteristics which were poorer than the international successful competitors in this sport. This paper may also motivate other countries to conduct similar research to establish a sharper focus on training programs to make their athletes more competitive in international competition even with some limitations due to non-modifiable characteristics.

This is the first study to use a systematic review approach in using anthropometric and physiologic test results in comparing elite taekwondo athletes. Of note was that the Filipino athletes (males and females) were significantly stronger than their counterparts in terms of leg power which gives them an advantage as the sport is characterized by bursts of sudden kicks. The male Filipino athletes were significantly shorter than the other athletes. The female Filipino athletes scored poorer than the other competitors in terms of flexibility and the one minute sit up test.

Sports performance may not depend solely on physical fitness as measured by anthropometric and physiologic testing, but a major emphasis is given in training to achieve high levels of physical fitness when engaging in sports competitions especially at the elite level.
Anthropometric testing has become indispensable in any sport when training at elite competitive levels, and when talent scouting. A physique matching the requirements of the sport is important in performance optimization. The nature of taekwondo involves fast and powerful kicks and therefore requires a lean physique [16]. Markovic and colleagues (2005) found that successful taekwondo athletes have lower body fat and are taller than less successful ones [13]. Taller athletes are believed to have an advantage over their opponents as they have a longer reach and a longer body 'lever' allowing them to attack the opponent in a short time, cover a larger distance and use smaller amounts of energy [15]. In the research reported in this paper, the current male Filipino elite athletes appear to be at a disadvantage as they were significantly shorter than their international counterparts. Height is not modifiable. Thus while the current cohort of elite athletes remain in competition, they need to develop techniques to compensate for their size. They should be trained to move more quickly, and to be more agile, to address their shorter strides. While the Filipino female athletes were no different from their international counterparts in height, similar training to the males would certainly not disadvantage them. The importance of height should be considered when talent scouting for future potential Olympians.

The comparison between the Filipino and international data for the physiologic tests, would appear to be useful for Filipino coaches and trainers as they highlight clear areas for improvement in training programs. Though the training program for the athletes was not assessed in this study, it might be reasonable to evaluate the program and use the results to modify and adjust the program based on the needs of the athletes. The female Filipino athletes did not perform as well as the Czech [12] or Croatian athletes in the sit and reach test [13], which was a measure of flexibility. Flexibility is an important component of fitness and performance in most sports especially in taekwondo [33]. The nature of the sport involves strong powerful kicks and repetitive leg movements. A higher level of flexibility allows greater range of movement, better execution of kicks and also prevents the occurrence of injuries. The female Filipino athletes therefore should probably include more flexibility exercises in their training programs to be competitive with their international counterparts. Kurz (1990) recommends ten minutes of dynamic leg swinging activities performed in the morning to achieve necessary flexibility for training within the day [34].

It was of note that in comparing the datasets, the test for leg power measured by the vertical jump test, both male and female Filipino 


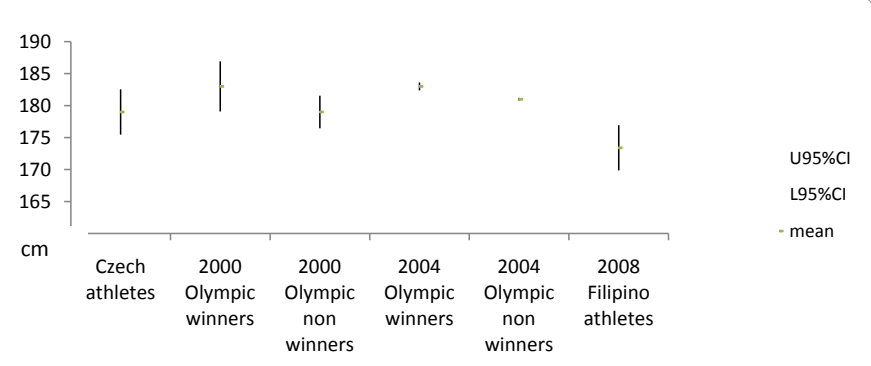

Figure 1: Height comparison of elite male taekwondo athletes.

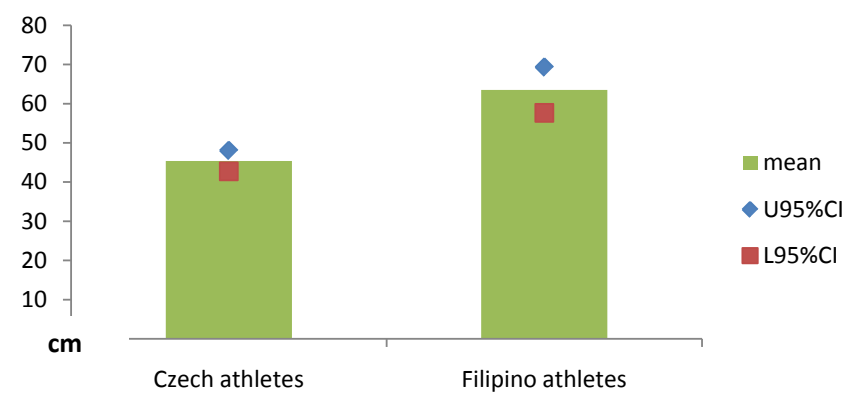

Figure 2: Comparison of elite male taekwondo athletes' leg power test.

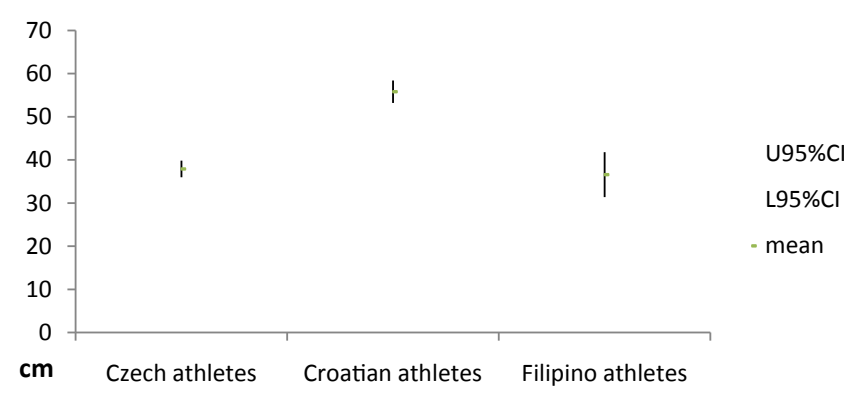

Figure 3: Comparison of elite female taekwondo athletes' flexibility test.

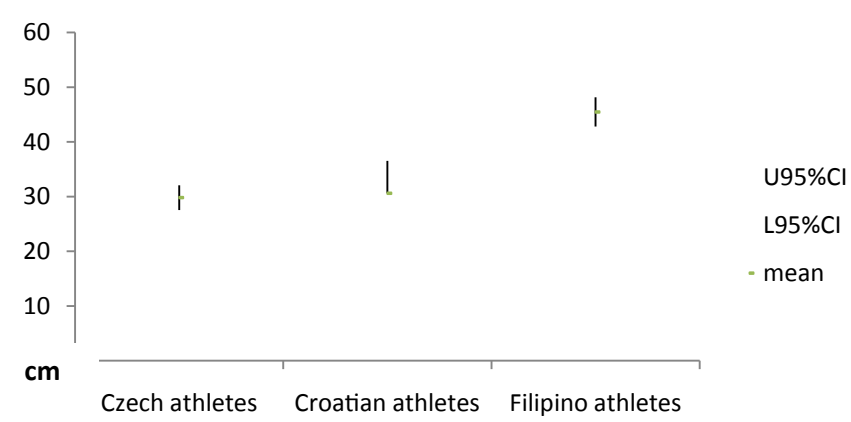

Figure 4: Comparison of elite female taekwondo athletes' leg power.

athletes performed significantly better than the other international athletes (Czech and Croatians). Leg power is probably one of the most important, if not the most important component in taekwondo. The sport is characterized by the execution of sudden bursts of powerful kicks and as reported by Kazemi and colleagues (2006), 98\% of techniques used to score the taekwondo Sydney Olympic were kicks
[15]. Knowing that Filipino athletes performed significantly better than the others in this component of fitness, they are considered to be at an advantage and therefore this should be maximized by the trainers. Enhanced leg power performance should be evident in skill performance during competition. Sports specific drills should be improved by the coaches, combined with training elastic strength with power and speed. Training for power at a sport specific velocity is considered optimal to improve competitive sport performance [35].

In the one minute sit up test, the female Filipino athletes had significantly lower results compared with the Croatian athletes. The test measures strength of the core (abdominal) muscles. It is known that core strength is an essential component of sports performance by ensuring stability of the trunk while performing the movement. This prevents injuries, in particular, back injuries. Recent studies show that exercises to improve core strength should always be incorporated during training across sports [36]. Therefore an additional training regimen for improving core strength should be undertaken among the Filipino athletes to surpass the level of their counterparts.

Three other tests (agility, sprint and aerobic power tests) were conducted for the Filipino athletes. However, the results of these tests were not used for international comparisons as there was no data available from the other studies (in the case of agility test) and if there were, a different test was used to measure the component (in the case of sprint and aerobic power test). These components are as important as the others and have been recommended by sports scientists and trainers to be included in test batteries [24]. These findings highlight the need for a standard battery of tests to assess the physiologic components which are important for taekwondo. These tests reflect important data on characteristics of sports participants, and therefore provide useful comparative and reference information for future sports participants.

\section{Conclusion and Recommendations}

The elite Filipino taekwondo athletes were comparable to other international elite athletes in most physical and some of the physiologic characteristics. As taekwondo is a sport that is characterized by bursts of explosive kicks, Filipino athletes should take advantage of the fact that they performed well in the leg power tests. Differences in performance between the Filipino elite athletes and the international elite athletes could be attributed to a number of factors, such as genetics, training programs, nutrition and socio-cultural influences. The findings presented in this paper should be considered in light of each of these factors, so that a greater scientific approach can be taken when designing athlete-specific, as well as team-specific training programs. Training programs that address the current physiological

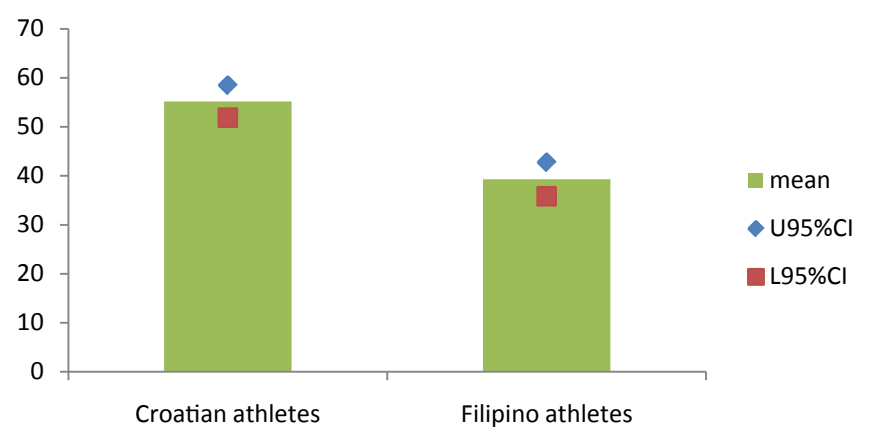

Figure 5: Comparison of elite female taekwondo athletes' one minute sit up test. 
Citation: Dizon JMR, Grimmer-Somers K (2012) Making Filipino Taekwondo Athletes Internationally Competitive: An International Comparison of Anthropometric and Physiologic Characteristics. J Sport Medic Doping Studie 2:105. doi:10.4172/2161-0673.1000105

Page 7 of 7

shortfalls should lead to improvements in national and international competition results.

It seems important that future studies be conducted to assess the effectiveness of training programs undertaken by Filipino athletes. A standardized set of tests used worldwide could be considered in order to provide comprehensive comparisons between athletes.

\section{Acknowledgement}

The authors would like to thank the following:

1. Ms Anthea Worley, International Centre for Allied Health Evidence

2. Dr. Alejandro V. Pineda, Jr., Medical Director of the Philippine Center for Sports Medicine, Philippine Sports Commission

\section{References}

1. Giampietro M, Pujia A, Bertini I (2003) Anthropometric Features and body composition of young athletes practicing karate at a high and medium competitive level. Acta Diabetol 40: 145-148.

2. Pieter W, Bercades LT, Kim GD (2006) Relative total body fat and skinfold patterning in Filipino national combat sport athletes. J Sports Sci Med (CSSI): 35-41.

3. McArdle WD, Katch FI, Katch VL (2003) Exercise Physiology: Energy, Nutrition and Human Performance. 5th Edition ed. Philadelphia, USA: Lippincott Williams \& Wilkins

4. Ribeiro JL, de Castro BS, Rosa CS, Baptista RR, Oliveira AR (2006) Heart rate and blood lactate responses to Changquan and Daoshu forms of modern wushu. J Sports Sci Med (CSSI): 1-4.

5. Aziz AR, Tan B, Kong CT (2002) Physiological responses during matches and profile of elite pencak silat exponents. J Sports Sci Med 1: 147-155.

6. Gabriel HW, Urhausen A, Valet G, Heidelbach U, Kindermann W (1998) Overtraining and immune system: A prospective longitudinal study in endurance athletes. Med Sci Sports Exerc 30: 1151-1157.

7. Kraemer WJ, Hakkinen K, Triplett-Mcbride TN, Fry AC, Koziris LP, et al. (2003) Physiological changes with periodized resistance training in women tennis players. Med Sci Sports Exerc 35: 157-168.

8. O'Toole ML, Hiller WD, Crosby LO, Douglas PS (1987) The ultraendurance triathlete: a physiologic profile. Med Sci Sports Exerc 19: 45-50.

9. Smekal G, Von Duvillard SP, Rihacek C, Pokan R, Hofmann P, et al. (2001) A physiological profile of tennis match play. Med Sci Sports Exerc 33: 999-1005.

10. Wisloff U, Helgerud J, Hoff J (1998) Strength and endurance of elite soccer players. Med Sci Sports Exerc 30: 462-467.

11. Franchini E, Nunes AV, Moraes JM, Del Vecchio FB (2007) Physical Fitness and Anthropometrical Profile of the Brazilian Male Judo Team. J Physiol Anthropol 26: 59-67.

12. Heller J, Peric T, Dlouha R, Kohlikova E, Melichna J, et al. (1998) Physiologica profiles of male and female taekwon-do (ITF) black belt. J Sports Sci 16: 243249

13. Markovic G, Misigoj-Durakovic M, Trninic S (2005) Fitness profile of elite Croatian female taekwondo athletes. Coll Antropol 29: 93-99.

14. Waggener GT, Boone T, Kasper M, Waggener AT (2007) Cardiovascular responses during karate exercise regimen and treadmill exercise at approximately 70\% HR intensity. J Exerc Physiol online 10: 29-34

15. Kazemi M, Waalen J, Morgan C, White A (2006) A profile of Olympic taekwondo competitors. J Sports Sci Med (CSSI): 114-121.

16. Zar A, Gilani A, Ebrahim Kh, Gorbani Mh (2008) A survey of the physical fitness of the male taekwondo athletes of the Iranian national team. Facta Universitatis 6. $21-29$

17. Lin WL, Yen KT, Doris Lu CY, Huang YH, Chang CK (2006) Anaerobic capacity of elite Taiwanese Taekwondo athletes. Med Sci Sports Exerc 21: 291-293.

18. World Taekwondo Federation (2009) Asian Taekwondo Union.

19. The Manila times http://www.manilatimes.net/national/2008.
20. Pieter W (1991) Performance characteristics of elite taekwondo athletes. Korean J Sport Sci 3: 94-117.

21. Kazemi M, Pieter W (2004) Injuries at a Canadian National Taekwondo Championships: a prospective study. BMC Musculoskelet Disord 5: 22.

22. Melhim AF (2001) Aerobic and anaerobic power responses to the practice of Taekwondo. Br J Sports Med 35: 231-234.

23. Gore JC (2000) Physiological tests for elite athletes: Australian Sports Commission. Australia: Human Kinetics.

24. Baechele T, Earle R (2008) Essentials of strength and conditioning , $3^{\text {rd }}$ edition National Strength and Conditioning Association ISBN-13: 9780736058032.

25. Norton K, Tim O (1996) Anthropometrica: A textbook of body measurement for sports and health courses. Sydney, Australia: UNSW Press.

26. Gabbett T, Kelly J, Ralph S, Driscoll D (2009) Physiological and anthropometric characteristics of junior elite and sub-elite rugby league players, with special reference to starters and non-starters. J Sci Med Sport 12: 215-222.

27. Foster TA, Berenson GS (1987) Measurement error and reliability in fou pediatric cross sectional survey of cardiovascular disease risk factor variablesthe Bogalusa Heart study. J Chronic Dis 40: 13-21.

28. Human Kinetics (2010).

29. Behm DG, Bradbury EE, Haynes AT, Hodder JN, Leonard AM, et al (2006) Flexibility is not related to stretch induced deficits in force or power. $J$ Sports Sci Med 5: 33-42.

30. Katic R, Blazevic S, Krstulovic S, Mulic R (2005) Morphological structures of elite karateka and their impact on technical and fighting efficiency. Coll Antropol 29: $79-84$

31. Leger LA, Mercier D, Gadoury C, Lambert J (1988) The Multistage 20M shuttle run test for aerobic fitness. J Sports Sci 6: 93-101.

32. Ramsbottom R, Brewer J, Williams C (1988) A progressive shuttle run test to estimate maximal oxygen uptake. Br J Sports Med 22: 141-144.

33. Donelly $P$ Factors in selection of optimal training methods for martial arts (with specific reference to taekwondo)

34. Kurz T (1987) Stretching Scientifically: A guide to flexibility training. Vermont USA: Stadion Publications.

35. Crewther B, Cronin J, Keogh J (2005) Possible stimuli for strength and powe adaptation, Acute mechanical responses. Sports Med 35: 967-989.

36. Saunders S (2007) Core stability and Exercise prescription, A research update: Implications for physiotherapists. Australian Sports Physiotherapy Magazine. 